"Information asymmetry on the market of non-banking financial services in Ukraine: causes, consequences, methods of control"

\begin{tabular}{|c|c|}
\hline AUTHORS & $\begin{array}{l}\text { Valentyna Levchenko iD https://orcid.org/0000-0001-8444-5960 } \\
\text { Myroslav Ostapenko }\end{array}$ \\
\hline ARTICLE INFO & $\begin{array}{l}\text { Valentyna Levchenko and Myroslav Ostapenko (2016). Information asymmetry } \\
\text { on the market of non-banking financial services in Ukraine: causes, } \\
\text { consequences, methods of control. Public and Municipal Finance, 5(1), 29-37. } \\
\text { doi:10.21511/pmf.05(1).2016.04 }\end{array}$ \\
\hline DOI & http://dx.doi.org/10.21511/pmf.05(1).2016.04 \\
\hline RELEASED ON & Tuesday, 19 July 2016 \\
\hline JOURNAL & "Public and Municipal Finance" \\
\hline FOUNDER & LLC "Consulting Publishing Company "Business Perspectives" \\
\hline & $\begin{array}{l}\text { E- } \\
\text { =-5 }\end{array}$ \\
\hline NUMBER OF REFERENCES & NUMBER OF FIGURES \\
\hline
\end{tabular}

(C) The author(s) 2023. This publication is an open access article. 
Valentyna Levchenko (Ukraine), Myroslav Ostapenko (Ukraine)

\title{
Information asymmetry on the market of non-banking financial ser- vices in Ukraine: causes, consequences, methods of control
}

\begin{abstract}
The article examines the features of the impact of information asymmetry on the key participants of the market of nonbanking financial services in Ukraine. It defines the basic reasons of its existence on the market.

The analysis of the consequences of information asymmetry for the functioning of non-banking financial services in Ukraine shows that it creates the conditions for opportunistic behavior and leads to adverse selection and moral hazard on the market.

Based on the research of existing methods and approaches to the reduction of information asymmetries the paper offers recommendations to overcome this problem on the market of non-banking financial services in Ukraine.
\end{abstract}

Keywords: information asymmetry, market of non-banking services, moral hazards, adverse selection JEL Classification: D82, G23.

\section{Introduction}

The market is not always able to provide an efficient allocation of resources and to produce the required quantity of benefits. In such cases, the scientific literature refers to market failures.

One of the "failures" of the market is its inability to provide access to full information about products, sellers and transaction conditions to all market participants. It is exactly this "failure" of the market that becomes increasingly relevant. This is related to the growing role of information in the economy and the formation of a fundamentally new type of economic system - information economy. In today's economy, the traditional factors of production and the key resources include not only classical land, labor, capital and entrepreneurial skills, but also information resources as an important element and factor of economic growth.

Information activity has become a significant element of market infrastructure of the modern society. At the same time, the uneven distribution of information, its uneven availability to different participants of the market leads to an advantage of some economic agents over others. This leads to deformation of the market mechanism and inefficiency of some components of the economic system (and sometimes, the whole system).

The situation, in which one part of economic players has access to a bigger volume of information than other economic players, is called information asymmetry. Information asymmetry leads to inefficiency of the market mechanism, which in turn can lead to economic crisis. With growing globalization and internationalization of economic and financial processes the problem of information asymmetry becomes increasingly relevant.

(C) Valentyna Levchenko, Myroslav Ostapenko, 2016

Valentyna Levchenko, Ph.D. (Ukraine).

Myroslav Ostapenko, Ph.D. Student, Education and Research Institute for Business Technologies "UAB” (Ukraine).
This problem manifests itself on financial markets in general, and non-banking financial services markets in particular. Imperfection and inefficiency of the market of non-banking financial services is explained by asymmetry of information.

Therefore, it is important to study the nature, causes and consequences of information asymmetries and to find methods to minimize it on the market for non-banking financial services in Ukraine.

The article is structured as follows. Section 1 is devoted to an overview of the literature on the chosen subject. Section 2 describes the causes of information asymmetry on the market of nonbanking financial services in Ukraine. Section 3 considers the main consequences of the existence of information asymmetry on the market of nonbanking financial services in Ukraine. Section 4 contains methods developed in the paper to reduce information asymmetry on the market of non-banking financial services in Ukraine. The final section contains conclusions and recommendations based on the results of the study.

\section{Literature review}

The problems of market imperfections and externalities were studied by Alfred Marshall and Arthur Pigou. Pigou introduced the phrase "market failures" into the scientific vocabulary. Further research of "market failures" was conducted by Coase, who showed that resources can be allocated ineffectively in the economy.

Coases' ideas were further developed by James Buchanan, Gordon Tullock, Mancur Olson, Kenneth Arrow and many others.

Systematization of the results of the studies dedicated to "market failures" was carried out by J.Stiglitz and S. Grossman (1980), who proposed their classification, emphasizing such failures as inefficient competition, collective goods, incomplete markets, externalities, 
cognitive restrictions and unemployment (inflation). Later, information asymmetry was added to this list.

The foundations of the theory of information asymmetry in the economy were laid by K. Arrow (1963) and G. Akerlof (1970). The latter built a mathematical model of the market with imperfect information, for which he received the Nobel Prize in 2001 (by the way, in 1996 the Nobel Prize was awarded to W. Vickreyand J. Mirrlees "for their fundamental contributions to the economic theory of incentives under asymmetric information" - that further proves the importance of the problem). G. Akerlof proved that due to imperfections of information dishonest sellers could offer low-quality products. The result of this is a falling demand for goods and their prices. As a result, sellers of high-quality goods disappear from the market or try to distinguish themselves from average manufacturers, which leads to additional costs.

Regarding the research methods of fighting information asymmetry, a significant role belongs to the works of Spence (1973).

Scientific works of Healy (1999), Leuz and Verrecchia (2000) indicate a connection between the level of information asymmetry and the level of information disclosure through the requirements to financial reporting.

\section{Causes of information asymmetry on the market of non-banking financial services in Ukraine}

The classical economic thought studies rational actions of economic players on the basis of information that is evenly distributed between them. But the real life shows that this is only an ideal model of market behavior and, in practice, it does not work, because its main provisions - the rational actions of players and the sharing of information between them are essentially abstractions that are only partially implemented.

The failure of complete rationalization of actions and behavior of economic players is connected with human psychology and the presence of different kinds of expectations, which have an individual character, not a universal nature.

Regarding the even distribution of information among business entities, it is unachievable in principle - someone always knows more than the other. This is due to the fact that some economic agents do not want others to know about the real state of their affairs or do not want to cause harm to themselves with their information (e.g., the sale of shares by the owner generates negative signals about the prospects of the company, because the owner would wish to hide information about his activities to avoid a damage to the company). Due to certain circumstances, other economic agents cannot pass information to others, because the transfer of information may be associated with additional costs and require additional loss of time. Quite often the receiving of information is accompanied by significant costs. Therefore, economic agents deliberately limit the level of their awareness. Thus, despite a significant development of information technologies and better access to information, as well as an increase in the volumes of available information, the problem does not diminish with time, but rather increases in scale.

The source of information asymmetry is uncertainty defined as the lack of information about the environment in which economic activity will be carried out and low predictability of these conditions. In its activity the contemporary economic entity closely interacts with different types of uncertainty:

1) situational uncertainty - caused by changes in the national and global economy, which have an impact on regions and individual economic entities;

2) institutional uncertainty - generated by differences, delay (lag) or lead in formal and informal constraints, incentives and mechanisms as objects of regulation;

3) time uncertainty - an impact of retrospective, current and prospective changes on the state of the object;

4) resource uncertainty - related to irrational distribution and changes of needs under the influence of technological uncertainty;

5) political uncertainty - related to the transformation of policy guidelines that determine the functioning of economic entities.

All kinds of uncertainties are closely related, and, in practice, it is not always possible to distinguish one from the other, which greatly complicates the decision-making process and may lead to unpredictable results.

The variety of causes and forms of manifestation of information asymmetry, the importance of the consequences of its existence for some economic subjects and market mechanisms, in general, have made information asymmetry a separate branch of microeconomics, which is steadily developing.

However, incompleteness of information concerns not only the products, but also the possible behavior of the parties to the agreement. One party of the agreement can act against the interests of the other party, resulting in additional costs to the other party. For example, a person who has insured a vehicle from theft would pay less attention to its safety. As a result, the risk of insured event would significantly increase for the insurance company. 
The problem of information asymmetry is one of the most universal in the economy, as it is present at all levels and in all spheres.

One of the "victims" is the market of non-banking financial services in Ukraine, which is represented by such economic entities as insurance companies, investment companies and investment funds, credit unions, factoring companies, pawnshops, leasing companies, pension funds and so on.

Here are some examples of information asymmetry on the market of non-banking financial services in Ukraine, which lead to the violation of market efficiency. The most typical examples are given in Appendix A (Table A.1).

The reasons for the existence of information asymmetry are related to the properties of information as such, the nuances of its perception and the behavior of some economic players in relation to others.

We will try to identify the main reasons for the existence of information asymmetry on the market of non-banking financial services in Ukraine:

1) limited access to information;

2) volatility and rapid aging of information;

3) incomplete understanding of information;

4) confidentiality;

5) the costs of obtaining information;

6) opportunistic behavior of the parties.

Summing up the results of the study of influence of information asymmetry on the market of nonbanking financial services in Ukraine, we can note that information asymmetry was one of the causes for the emergence of the global financial crisis. It is well known that the catalyst of the crisis were mortgage-backed securities in the US and transactions with them. Issuers of these securities had a significantly greater amount of information about their real quality and the quality of mortgage loans that were behind them. However, using this information advantage, they were said to be high-quality and almost risk-free. The consequences of this are felt by the global economy to this day.

\section{Consequences of information asymmetry for the market of non-banking financial services in Ukraine}

The existence of information asymmetry is a serious threat to the market mechanism on all levels of the economy - from relations between individual economic players to the collapse of some markets and inefficiency of the economic system as a whole.

Information asymmetries in the market economy are linked to the existence of the so-called " 6 major puzzles of international economy" - inconsistencies between the real-life and classical economic theories that were formulated by M. Obsfeld and K. Rogoff (2000).

J. Stiglitz (1974) showed that the existence of information asymmetry denies a number of modern "theories of the firm". For example, according to the theory of corporate governance, firms try to maximize profits in the process of their own activities. However, with a high level of information asymmetry, the divergence of interests of the managers and shareholders leads to the managers pursuing their own goals, which may not coincide with the goals of the company, including profits maximization.

The existence of information asymmetry may cause a so-called opportunistic behavior - behavior that is aimed at achieving one's own interests, usually contrary to the interests of others, unrestricted by considerations of morality, that is, associated with deception, trickery and deceit.

Opportunistic behavior is the behavior of an individual, who aims to get one-way benefits by evading the conditions of a contract.

There are three types of opportunistic behavior that correspond to different types of information asymmetry:

1. The buyer is unaware of the quality characteristics of goods, there is asymmetry of information that is called "hidden characteristics", which can lead to adverse selection.

2. Hidden action/hidden information that lead to moral hazard of the party who owns the information.

3. Hidden intentions of a partner to the agreement are fraught with the danger of the third type of opportunistic behavior - extortion (hold-up).

In terms of the contractual process, opportunistic behavior is divided into two types - pre-contractual (occurs at the stage of conclusion of economic agreements, which is based on disparity of information for different parties to the contract regarding the characteristics of its object) and post-contractual (occurs after the conclusion of a contract and is related to the breach of contract by one party for its own benefit to the detriment of the other party).

Opportunistic behavior leads to a number of negative consequences, some of which are losses from opportunistic behavior, the costs of preventing opportunistic behavior to control the behavior of economic agents and the cost of reducing information asymmetry. Other consequences of opportunistic behavior on the basis of information asymmetry are more fundamental and related to the efficiency of the market mechanism as a whole. An example of the latter is the existence of the shadow sector, which is based on information asymmetry and opportunistic behavior. 
According to J. Stiglitz (2003), with incomplete, inaccurate and asymmetric information, it is impossible to achieve a general market balance. The asymmetry of information is the cause of "adverse selection", environmental pollution, increased moral hazard and other "market failures".

Analyzing the scientific literature on the problems of information asymmetry, we can make a conclusion that negative consequences of its existence have two forms - ex ante consequences, which are called adverse selection and ex post consequences, which are called moral hazard.

We will analyze the nature and manifestations of these forms of negative consequences of the existence of information asymmetry.

1. Adverse selection - a situation in which due to the existence of information asymmetry in the market, "good" products are replaced by "bad" ones. The losses from this phenomenon are felt by both the sellers and the buyers of the quality goods. The only ones who remain in positive territory are the sellers of "bad" low-quality goods. Adverse selection is the result of opportunistic behavior.

We will use credit market as an example. For the creditor, it is difficult to assess the real capabilities of the borrower. If he cannot distinguish good borrowers from bad borrowers, he would definitely face the problem of adverse selection. As a result, the creditor would lend at higher rates trying to compensate for the risks of unreliable debtors. As a result, good borrowers would have to pay higher interest rates than they could pay based on their quality. This would cause some borrowers to abstain from loan services. Therefore, adverse selection would reduce lending, respectively, reducing investments into the economy and economic activity, in general. Regarding the fate of the banking sector in this situation, then credit rates would continue to rise, as the quality of loan portfolios would be falling as a result of reduction in the number of reliable borrowers. The profits of banks would be falling. The size of the credit market would decrease. Ultimately, it could lead to the collapse of the credit market.

Another classic area with a high level of information asymmetry and a pronounced adverse selection mechanism is insurance. We will consider the example of life insurance. The insurance company, setting the amount of insurance payments, bases its decision on the average probability of potential insured event, the calculation of which usually includes a large number of customers with good health (the probability of an insured event would be low) and a number of customers with health problems (with higher probability of an insured event). Not very big premiums would attract people in poor health. As a result, the average probability of an insured event increases, forcing insurance companies to raise their rates. The result of the rates' increase would be the withdrawal of customers with good health, because they would be assessing insurance costs to be greater than the risk of the insured event. The insurance company is basically left with customers with higher probability of the insured event. The action of the company is obvious - a further increase in rates. This happens over and over again until either the company will cease to be profitable, or its customers refuse to pay insurance premiums. What follows is deformation and disappearance of the market.

2. Moral hazard is a risk associated with dishonesty of one (or both) parties to the agreement. A moral hazard may occur where the actions of one party may change to the detriment of another. It is the activity of economic agents aimed at maximizing their own profits to the detriment of others because of information inequality and differences in interests manifested in the changing behavior of one party after the agreement has been signed. For example, the insured person would pay less attention to the safety of insured object. Moral hazard is a result of post-contractual opportunistic behavior.

Situations, in which there is a moral hazard, are characterized by a combination of certain conditions:

- the interests of the principal and agent do not coincide - the agent pursues his own interests against the interests of the principal;

- the agents are insured against the adverse consequences of their actions;

- the principal is unable to carry out full control.

A specific manifestation of moral hazards is a principal-agent problem. This dilemma exists in circumstances where the agent is motivated to act in his own best interests, which are contrary to those of the principal, and is an example of moral hazard. As a result, employees have an opportunity to use this information asymmetry and not work to their full potential. In other words, employees begin to pursue their own interests, ignoring the interests of the owner and the company in general. This is just one scenario of realization of this problem. In fact, not only the business owner can be a principal, but also other physical person, entity, or even the state. Agents can include not only employees, but also other physical and legal persons that come into contractual relations with principals, when one party receives a fee from the other party for certain services.

An important problem, which is a direct consequence of the existence of information asymmetry, is the additional cost of information verification (costly state verification) - the fact that verification or disclosure of information about the counterparty as well as the monitoring of information have very significant costs. 
However, the reluctance to incur additional costs of verification and monitoring of information about the counterparty, according to the research of R. Townsend (1979), can lead to what is ultimately the result of information asymmetry in monetary terms that can be equal to the amount of debt of the counterparty, when the procedure of bankruptcy against him is initiated. In this case, information asymmetry will disappear, but the costs of its disclosure will be maximal. The institute of bankruptcy can act as an instrument for reducing information asymmetry post factum. Consequently, in order to prevent high costs of losing the entire amount of debt, it is necessary to take costly measures monitoring the information about the status of the counterparty.

The development of non-banking financial services market in Ukraine is directly related to the level of financial culture, financial education and awareness of the population. The low level of financial culture in the conditions of information asymmetry leads to opportunistic behavior not on the part of the customers of financial institutions, but rather on the part of financial intermediaries themselves. Companies, by using the ignorance of customers and the low level of financial literacy, artificially inflate the costs of financial services, set rates and fees in the amounts that do not correspond to their actual value, forming the so-called syndrome of "forced consumption" (e.g., realization of salary projects imposed payment cards and related banking services upon the public).

Regardless of the forms of information asymmetry, it has a significant negative impact, the result of which is a decrease in the efficiency of decisions made by market participants, low efficiency in the functioning of some markets and the economy in general.

\section{Methods of fighting information asymmetry on the market of non-banking financial services in Ukraine}

Given the importance of the problem of information asymmetry and the consequences that accompany it, it is necessary to organize research to identify the main methods and approaches to reduce and overcome information asymmetry.

According to G. Akerlof (1970), the problem of information asymmetry has only two ways of solving - through guarantees and reputation. It is possible to realize guarantees only through courts, while good reputation is only possible in an open society (a society in which every citizen has access to information about all companies and sellers).

The basis of methods for fighting information asymmetry is the "theory of market signals" developed by
M. Spence (1974), according to which sellers have to provide additional information about the quality of their products. This could ensure a counterbalance to adverse selection and retain market efficiency. In addition, logos, trademarks, firm's reputation, quality certificates, diplomas of various competitions and prestigious nominations, recommendations, qualifications and payment of dividends are signals of prosperity and good prospects (Leuz and Verrecchina, 2000).

There are special state agencies that serve as institutes of guarantees and insurance. For example, the existence of the Deposit Guarantee Fund sends to investors a signal about the reliability of the banking system, thereby reducing the level of information asymmetry between the population and the banking system.

It is possible to identify the instruments of business entities that could be an alternative or be used together with the market signals of M. Spence. In particular, this is price discrimination. It, in its various forms, can very effectively counteract information asymmetry and its consequences. Setting different prices for different customers can reduce moral hazards and help to resist adverse selection. For example, a healthy person, for whom the probability of an insured event (for health insurance) is low, would pay lower premiums than a person with health problems, who, accordingly, would pay higher premiums, because the probability of occurrence of the insured event is significantly higher.

Clearly defined sanctions and responsibility for breach of contracts can significantly reduce moral hazards and opportunistic behavior.

The monitoring of contracting parties and their economic activity, despite its costs, can significantly reduce the likelihood of financial losses as a result of information asymmetry.

Another element of reducing the negative effects of information asymmetry is the company's equity. Its high level, coupled with stable and significant net profits is a guarantee against opportunistic behavior, because, as in the case with the pledge, the company has what to lose.

In the case of investments into the company, a potential method of reducing opportunistic behavior in relation to the investor is the use of so-called debt contracts. These are commitments of the company to pay a certain fixed amount to the investor as income on his investment. This approach, in contrast to the investor's participation in profits and getting his share based on the results, reduces the likelihood of moral hazard and opportunistic behavior on the part of the company's managers. When the investor participates in profits and does not take part in the operational management, the company's managers 
have incentives to understate the company's income to reduce payments to the investor or to engage in activities that are beneficial for them personally, but not for the company as a whole. In the case of debt contracts, when the company has to pay fixed payments, it is not profitable for managers to understate profits. For them, it is more profitable to work with maximum efficiency, because the more profits the company receives, the more money is left in its possession after payments to the investor and which may be used for bonuses to pay the managers. In this case, it does not matter to the investor how the company's managers behave, because he would receive earlier stipulated amount notwithstanding the size of profits. Therefore, investors do not need to spend money on constant monitoring of the company's management. The need for such expenditures arises only in case of the company's default.

An important group of methods associated with information asymmetry and the behavior of top managers is their insider activity. It refers to operations with the company's securities. Possession of unique information about the current and future state of the company provides its managers with an opportunity for speculations. In other words, to materialize information inequality. To prevent this behavior the following methods are used: disclosure by insiders of key information about the number of shares they own; restrictions on securities transactions by insiders.

Therefore, insider activity falls under the control of both the state and shareholders, as well as other members of the exchange activity. This leads to the reduction of information asymmetry and reduces the possibilities for its use and realization of economic benefits.

The amnesty of capital is relevant for Ukraine and a large number of developing countries as a method to reduce information asymmetry at the level "state business entities". Shadow economy is a typical consequence of information asymmetry in developing countries making more than $50 \%$ of the legal sector. By virtue of their nature, shadow funds cannot be transformed into capital (without additional costs) and be beneficial for the economy (at least, this benefit would be very limited, especially for the state and its budget). The amnesty of capital can be an escape from this difficult situation.

We can also identify a set of methods that have a purely informative nature. This is, for example, a creation of various specialized databases (credit and insurance history, a register of traffic and other offenses, etc.). An important component of the modern global financial system, which counteracts information asymmetry, is the existence of rating agencies and their assessments, which are carried out at the level of individual states and businesses and which contribute to better understanding of the state of an economic entity. At the level of "management-shareholders", information asymmetry can be reduced by monitoring the company's activities by shareholders. An audit or verification of managers can serve as a specific instrument in this case.

The most common approach that can reduce information asymmetry on different types of markets is the use of intermediaries.

Depending on their role in overcoming information asymmetry intermediaries in the economy can be divided into two groups:

- financial and economic intermediaries economic actors that, due to their core activities, contribute to the reduction of information asymmetry in the economy;

- information intermediaries - economic actors whose main activity is to supply the market with information and information services, which lead to the reduction of information asymmetry.

For example, venture firms, by means of careful pre-investment examination, continuous monitoring of business activities and financial position of the company, create the image of this company, reducing the level of asymmetry around it and forming an idea of its real value. B. Black (1998) distinguishesventure firms as not only financial or information intermediaries, but also offers to use a specific class of intermediaries - reputation intermediaries.

An important class of intermediaries who contribute to the reduction of information asymmetry is information intermediaries. They include accounting firms, rating agencies, financial analysts, consulting firms and others.

Auditors, who form an audit opinion about the financial statements of companies, form the credibility of the companies in the eyes of potential investors, affecting their investment decisions. S. Kothari (2000) notes that the reaction of share prices of companies to the announcement of their financial statements confirms that investors generally believe that such accounting information of companies is trustworthy. In turn, this trust was formed largely through its confirmation by independent auditors and their reputation. In general, the experience of capital financing in the Western countries shows that investors require from companies the availability of conclusions of independent auditors, even if there are no specific demands from government regulators. In other words, the participation of auditors enhances the creditworthiness of companies in the eyes of potential investors. The research results 
suggest that, in general, auditors do not provide markets with new information about companies or their condition; they only confirm the existing information.

Rating agencies, which assign credit ratings for issuers and their debt obligations, also play an important role among information intermediaries. They indirectly, through ratings (rating is an opinion of the rating agency on the creditworthiness of the rating's object in general, its individual debt obligation or other financial instruments expressed as a score on a scale of credit ratings), give signals to economic entities about the state of others. The existence of the company's rating can open or close the sources of funds, improve its reliability in the eyes of investors or reduce it. In any case, the ratings significantly reduce the level of information asymmetry. Today, they are one of the most effective and efficient instruments to reduce information asymmetry on investment markets, including international ones.

Historically, the role of information intermediaries on financial markets is performed by financial analysts, who by gathering information from public and private sources assess the current state of a company, make predictions about its future prospects and give recommendations whether to buy or to sell the company's securities. The research findings about the activity of financial analysts on capital markets suggest that financial analysts make an impact on the value of companies. Moreover, the forecasts of analysts are typically better than the usual analysis of a company or its share prices, because they take into account not only internal information, but also the information about the external environment economic news, political events, etc.

As an additional class of intermediaries, some researchers distinguish the so-called reputational intermediaries - economic subjects, who, by participating in a particular transaction, by their reputation guarantee the transparency and fairness of contracts as a way reducing the level of information asymmetry. An example of reputational intermediaries can be investment banks that act as underwriters during, for example, the initial placement of securities of certain issuers. In this case, investors may not have sufficient information about the economic entity, whose securities they are going to buy, although the reputation of the bank doing the placing signals to them about their high quality, thereby reducing the level of information asymmetry. Reputational intermediaries also include auditing firms, whose main asset is their reputation that was created during the decades on the market. Another example is the fate of the audit firm "Arthur and Andersen" (which was among the top five biggest accounting firms in the world), which, after the scandal with the "Enron" company, had to cease its existence as a result of the lost reputation.

\section{Conclusion and recommendations}

An effective functioning of the market of nonbanking financial services in Ukraine is impossible without solving a number of fundamental problems. One of them is information asymmetry - a situation where one part of economic players has a bigger volume of information than other economic players.

The article examines how information asymmetry affects insurance companies, investment companies and investment funds, credit unions, factoring companies, pawnshops, leasing companies, pension funds, etc., and determines the basic reasons of its existence on the market.

The analysis of the consequences of information asymmetry for the functioning of non-banking financial services in Ukraine shows that it creates the conditions for opportunistic behavior and leads to adverse selection and moral hazard.

Based on the existing research methods and approaches to reducing information asymmetry, the paper offers recommendations to counteract this problem on the market of non-banking financial services in Ukraine.

The proposed recommendations include the rationale for strengthening the role of reputation in the activities of financial companies in Ukraine, more conscious use by the state of institutions of guarantees and insurance (in particular, proposals regarding the establishment of a special institution that promotes foreign direct investments in Ukraine, which could serve as guarantor for investors), creating conditions for active development of the socalled information and reputation intermediaries, and improving the regulations and state control over the use of insider information on the market of nonbanking financial services in Ukraine. Moreover, it is important to strengthen the fight against corruption and bribery and ensure further development of state regulation of the market based on the modern approaches and international standards.

\section{References}

1. Akerlof, G. (1970). The Market for Lemons: Quality Uncertainty and the Market Mechanism, Quarterly Journal of Economics, 84, pp. 485-500.

2. Arnott Richard, J., Stiglitz Joseph, E. (2004). The Basic Analytics of Moral Hazard. NBER Boston College and Columbia Business School - Finance and Economics. 
3. Arrow, Kenneth, J. (1963). Uncertainty and the Welfare Economics of Medical Care, American Economic Review, 53 (5), pp. 941-973.

4. Black Bernard, S. (1998). Information Asymmetry, The Internet, and Securities Offerings, Journal of Small and Emerging Business Law, Vol. 2., pp. 91-99.

5. Greenwald Bruce, C.N., Stiglitz Joseph E. (2007). Imperfect Information, Credit Markets and Unemployment. NBER Working Paper No. w2 093.

6. Grossman, S., Stiglitz, J. (1980). On the Impossibility of Informationally Efficient Markets, American Economic Review, 70. pp. 393-408.

7. Healy, P. M., A.P. Huttonand, K.G. Palepu. (1999). Stock performance and intermediation changes surrounding sustained increases in disclosure, Contemporary Accounting Research, 16, pp. 485-520.

8. Hillier, B. (1997). The Economics of Asymmetric Information. MacMillan Press Ltd., USA.

9. Hubbard, R. (2002). Money, the Financial System, and the Economy. New York: McGraw-Hill, Inc.

10. Kothari, S.P. (2000). Capital Markets Research in Accounting. JAE Rochester Conference April 2000 Massachusetts Institute of Technology (MIT) - Sloan School of Management. Working Paper Series.

11. Leuz, C. and R.E. Verrecchia. (2000). The economic consequences of increased disclosure, Journal of Accounting Research, 38, pp. 91-124.

12. Mirrlees James, A. (1996) Information and Incentives: The Economics of Carrots and Sticks: Nobel Lecture. Dec. / By Faculty of Economics and Politics, University of Cambridge, England [Online]. Available at: http://www.nobel.se/economics/laureates/.

13. Obsfeld, Maurice, Rogoff, Kenneth. (2000). The Six Major Puzzles in International Macroeconomics: Is There a Common Cause? In Bernanke, Ben, Rogoff, Kenneth. NBER Macroeconomics Annual 2000. The MIT Press. pp. 339-390.

14. Schmid Linda, Klein Thomas, J. (2002). Debt vs. Equity and Asymmetric Information: A Review, The Financial Review. August.

15. Spence, M. (1973). Job Market Signaling, The Quarterly Journal of Economics, Vol. 87.

16. Spence, M. (1974). Market Signaling. Harvard University Press.

17. Stiglitz, J.E. (2003). Information and the Change in the Paradigm in Economic, The American Economist, 47 (2).

18. Stiglitz J.E., Weiss, A. (1981). Credit Rationing in Markets with Imperfect Information, The American Economic Review, 71, (3) (June), pp. 393-410.

19. Townsend, R.M. (1979). Optimal contracts and competitive markets with costly state verification, Journal of Economic Theory 22, pp. 265-293.

20. Vickrey, W. (1961) Counter speculation, auctions and competitive sealed tenders. Columbia University.

\section{Appendix A}

Table A.1. Examples of information asymmetry on the market of non-banking financial services in Ukraine

\begin{tabular}{|c|c|}
\hline Type of market activity & Examples of the impact of information asymmetry \\
\hline Purchase/sale of financial services & $\begin{array}{l}\text { 1. The seller knows about his product/service (its quality and other characteristics) more than the buyer. As a } \\
\text { result, the buyer often pays the price that is inadequate to the real value of goods/services. } \\
\text { 2. Formally, the terms of the contract create conditions for opportunistic behavior in relation to each other. The } \\
\text { threat depends on how the contract performer begins to execute these formal commitments. If he has no incen- } \\
\text { tives to behave honestly, his actions may cause damages to the other party. } \\
\text { 3. Financial intermediaries tend to possess more information than a regular buyer and they are supposed to act in } \\
\text { the interests of the buyer. However, under conditions of information asymmetry, financial intermediaries have an } \\
\text { opportunity to receive higher profits by offering the buyer the goods at higher prices and of lower quality. }\end{array}$ \\
\hline Lending activity & $\begin{array}{l}\text { 1. The client borrows money without collateral. Obviously, the debtors know better than credit unions whether they } \\
\text { will repay the debt or not. In addition, the debtor cannot take active actions to return the debt. For example, if the } \\
\text { customer does not care about the repayment of the debt, he can quietly agree to be fired. This, of course, will } \\
\text { deprive him of the ability to repay the debt to the credit union. } \\
\text { 2. Credit unions can not always control the actions of borrowers after receiving loans. The borrower can carry out } \\
\text { activities that increase the risk of insolvency or seek to hide income from investments to avoid paying the debts. The } \\
\text { result of this is a decline in the volume of lending and setting of high interest rates. }\end{array}$ \\
\hline Insurance & $\begin{array}{l}\text { 1. If it is impossible to divide customers into groups according to the degree of risks, insurance companies set a } \\
\text { single size of premiums. As a result, customers with low risk levels overpay for the risk. The consequence of this is } \\
\text { ineffective functioning of the market and inefficient allocation of resources. As customers with low risk levels } \\
\text { disappear from the market, customers with a high risk level, in contrast, will be entering the market. As a result, the } \\
\text { costs of insurance companies will grow leading to an increase in premiums for all and to an increase in social } \\
\text { expenditures. } \\
\text { 2. Insurance reduces the incentivesof the insured party to adopt preventive measures: } \\
\text { homeowner who is less concerned about locking his house when it is insured; } \\
\text { the owner of a car, who drives it carelessly because it is insured; } \\
\text { a person pays less attention to his health, because it is covered by his medical insurance. }\end{array}$ \\
\hline
\end{tabular}


Table A.1 (cont.). Examples of information asymmetry on the market of non-banking financial services in Ukraine

\begin{tabular}{|l|l|}
\hline Investment activity & $\begin{array}{l}\text { 1. The existence of the so-called "6 puzzles" in the sphere of internationalfinance. For example, home equity bias } \\
\text { is linked by many scientists to information asymmetry and the need for additional costs to overcome it. When } \\
\text { investors, despite the need to diversify the investment portfolio, prefer to make internal investments. } \\
\text { 2. In the case of securities the problem of asymmetric information manifests itself in the fact that their issuer has more } \\
\text { information than the investor regarding the quality of the offered securities and the state of the company that issues them. } \\
\text { The lack of sufficient information about the securities may cause investors not to buy the morto require raising the profits on } \\
\text { such securities as compensation for risks. } \\
\text { 3. Information asymmetry leads to the appearance and collapse of stock bubbles. }\end{array}$ \\
\hline $\begin{array}{ll}\text { 1. With asymmetric information (an employee knows exactlyhow much work he did, but his employer has only an } \\
\text { approximate understanding of this) there are both incentives and opportunities to workless. If the contribution of } \\
\text { every employee to the overall performance is measured with major mistakes, his reward is poorlyconnected to his } \\
\text { actual performance. Hence - negative incentivesthat lead to sabotage in the worst case and less efficientwork in } \\
\text { best best case. } \\
\text { 2. The interests of owners and employees often donot coincide. As a result, employees pursue their own interests, } \\
\text { not the interests of the company where they work. } \\
\text { 3. Asymmetry of information manifests itself on the stage of hiring of employees. At this point, the employer does } \\
\text { not know the real quality of the purchased "goods". } \\
\text { 4. Another aspect of information asymmetry is that many companies inflate wages, because they understand: on } \\
\text { the one hand, high wages require more intense work and formation of the high corporate culture, on the other - it } \\
\text { causes higher potential losses for employees in case of their firing. }\end{array}$ \\
\hline
\end{tabular}

